GRASAS Y ACEITES 66 (2)

April-June 2015, e070

ISSN-L: 0017-3495

doi: http://dx.doi.org/10.3989/gya.0946142

\title{
Influence of alternating air injection on the color and "alambrado" of natural black olives cv. Arauco, as compared with the traditional Argentine method
}

\author{
J.A. Juarez Romero ${ }^{\mathrm{a}, \varpi}$, G. Denoya ${ }^{\mathrm{b}}$ and G. Polenta ${ }^{\mathrm{b}}$ \\ ${ }^{\text {a }}$ Laboratorio de Industria y Sanidad Olivícola, INTA, Aimogasta, La Rioja, Argentina \\ 'Instituto en Tecnología de los Alimentos, INTA, Castelar, Buenos Aires, Argentina \\ Corresponding author: juarez.julio@inta.gob.ar
}

Submitted: 14 September 2014; Accepted: 01 December 2014

SUMMARY: Ripe black olives cv. Arauco were processed under different conditions to evaluate the effects of alternating air injection (AI) on the color of olives and on spoilage known as "alambrado", using a system based on the one patented by the "Instituto de la Grasa" (Sevilla, Spain), as compared with the traditional Argentine processing method, which consists of drying the olives in natural air ("extendido") for 24 hours at 7, 14 and 21 days of fermentation. Four types of fermentation were used: brine at $2 \% \mathrm{NaCl}$ plus $\mathrm{AI}$; brine at $2 \% \mathrm{NaCl}$ plus three "extendidos"; brine at $9 \% \mathrm{NaCl}$ plus three "extendidos"; and brine at $9 \% \mathrm{NaCl}$ plus $\mathrm{AI}$ and one "extendido". As previously observed in other varieties by other authors, we noticed that lower $\mathrm{pH}$ values were achieved in $2 \% \mathrm{NaCl}$ fermentations vs. $9 \% \mathrm{NaCl}$ fermentations. AI prevented the "alambrado" whereas brine at $2 \% \mathrm{NaCl}$ reduced this spoilage as compared with brine at $9 \% \mathrm{NaCl}$. The darkest color of olives was obtained with three "extendidos", but $83 \%$ of brightness reduction was achieved with only one "extendido". The "extendido" process decreased the texture. We conclude that the combination of AI and "extendido" can add benefits to natural black olives of the Arauco variety.

KEYWORDS: Alternating air injection; Cv. Arauco; Natural black olives; Spoilage of "alambrado"

RESUMEN: Influencia de la inyección alternante de aire en el color y el "alambrado" de aceitunas negras naturales Arauco c.v., en comparación con el método tradicional argentino. Se elaboraron aceitunas negras maduras variedad Arauco en distintas condiciones para evaluar la inyección alternante de aire (IA) con un sistema basado en el patentado por el Instituto de la Grasa, en comparación con la elaboración tradicional argentina donde se realiza exposición al aire en seco ("extendido") de los frutos durante 24 h, en tres momentos de la fermentación (después de 7, 14 y 21 días). Se hicieron cuatro tipos de fermentaciones: en salmuera al 2\% con IA; en salmuera al $2 \%$ y $9 \%$ con tres "extendidos" y salmuera $9 \%$ con IA y un "extendido". Se alcanzaron los valores mas bajos de $\mathrm{pH}$ en fermentaciones con el $2 \%$ de $\mathrm{NaCl}$ versus las de $9 \%$. La IA evita el defecto de "alambrado" y lo reduce la concentración de $2 \%$ versus la de $9 \%$. El color más oscuro se obtiene aplicando el "extendido" en tres oportunidades, pero con una aplicación se alcanza el 83\% de la reducción de luminosidad alcanzada por las tres aplicaciones. La textura se ve disminuida por el proceso de "extendido". La combinación de la IA y el "extendido" reducen el defecto de "alambrado" y oscurecen las aceitunas negras al natural de la variedad Arauco.

PALABRAS CLAVE: Aceituna negra al natural; Defecto de "alambrado"; Inyección alternante de aire; Var. Arauco

Citation/Cómo citar este artículo: Juarez Romero JA, Denoya G, Polenta G. 2015. Influence of alternating air injection on the color and "alambrado" of natural black olives of cv. Arauco, as compared with the traditional Argentine method. Grasas Aceites 66 (2): e070. doi: http://dx.doi.org/10.3989/gya.0946142.

Copyright: (C) 2015 CSIC. This is an open-access article distributed under the terms of the Creative Commons Attribution-Non Commercial (by-nc) Spain 3.0 Licence. 


\section{INTRODUCTION}

The production of black olives cv. Arauco is of great importance in the province of La Rioja in Argentina. The olives of this variety are used for different purposes, but in the region of Aimogasta and Mazan (Dto. Arauco, La Rioja) they are used mainly for the preparation of natural black olives since the product obtained is of excellent quality and highly valued in international trade (Balastsouras, 1996). The main defect in the processing of this product is the spoilage known as "alambrado", which consists of cracks formed in the pulp, which affect the quality of the texture of the olives.

In the eighties, research began to study and quantify this defect in Spanish varieties (Balastsouras, 1996; García-García et al., 1982) by cutting and observing the fruit pulp (García-García et al., 1982). These studies showed that intermittent air injection (AI) during fermentation significantly reduces the "alambrado" in some varieties (García-García et al., 1982; Duran Quintana et al., 1986; García-García et al., 1985). These studies also showed that this technological alternative induces a greater darkening of the olives with regard to the treatment without aeration and thus prevents the need to air-dry the olives in order to darken them (Barranco et al., 2007). Therefore, this technique would also be of interest to obtain the desired color of this type of olives.

In Argentina, the total time of fermentation of natural black olives is between 60 and 90 days. The fermentation process includes a stage called "extendido", which consists of drying the olives in natural air to darken them, a process usually done at 7, 14 and 21 days of fermentation (Lúquez Bibiloni and Aguilera Radic, 2006). The "extendido" is laborconsuming and brings about hygiene problems by excessive handling and exposure to environmental pollution (Gobierno de la Pcia. de La Rioja, 2005; Romero, 1999).

One of the attributes most valued by consumers in this type of product is the dark color. However, using the traditional Argentine processing method, the intensity and homogeneity of the color never reach those of the olives processed according to the Californian type. Still, in the Argentine market, natural black olives have wide acceptance. Detailed studies of the productive process have shown that the concentration of the fermentation brine is an important factor in the development of the "alambrado", measured as a percentage of affected fruits. It has been shown that olives fermented in brine with low concentrations of $\mathrm{NaCl}(2 \%)$ have a lower incidence of the defect than those fermented in higher concentrations (9\%) (Duran Quintana et al., 1986; García-García et al., 1982; García-García et al., 1985).
The aim of this study was to compare the color, texture and $\mathrm{pH}$ of natural black olives processed according to the traditional Argentine method with those of olives processed with AI, without "extendido" and with two different saline concentrations during fermentation. Color, texture and conservation were chosen to evaluate the most critical characteristics in this type of processing, and the product analyses were designed to describe these features. This research involves a specific objective within the general aim of a project of our lab which consists of improving the processing conditions of natural black olives, mainly regarding quality and cost, without modifying the positive features that make the product valued on the market.

\section{MATERIALS AND METHODS}

\subsection{Conditions of the fermentation process}

Black olives of the cv. Arauco from a traditional field of Aimogasta (province of La Rioja, Argentina), harvested with a Ferreira maturity index (1979) greater than 4 (Barranco et al., 2007), were used. Olives were fermented in 100-L high-density polyethylene containers filled with olives and brine. A system based on this one was patented by the Instituto de la Grasa (Sevilla, Spain), in which the circulation and mixing of fluids are the result of currents of air introduced into the base of the container with a tube used for the injection of air. The liquid goes up the column due to the lower density of the liquid-gas mixture inside and because it is dragged by the bubbles formed when the air introduced decompresses and disperses (García-García et al., 1985).

To inject the air, an air flow related to the capacity of the container is recommended: $0.3 \mathrm{~L}$ of air $\mathrm{h}^{-1}$ for each L of container capacity, i.e. for a container of $100 \mathrm{~L}$ you should inject $30 \mathrm{~L} \cdot \mathrm{h}^{-1}$ air. The references consulted only mention a tube diameter of $120 \mathrm{~mm}$ for a container of $16000 \mathrm{~L}$; thus, to choose the diameter of the tube, we decided to match the speed of the air with the ventilation hose recommended in the literature (Garrido-Fernández et al., 1985; GarridoFernández et al., 1991). Since the tube recommended is $120 \mathrm{~mm}$ in diameter for a container of $16000 \mathrm{~L}$ and the recommended flow is $0.3 \mathrm{Vol}$. air/ (mean Vol. $\mathrm{x} \mathrm{h}$ ), then, for a container of $100 \mathrm{~L}$, the diameter required to match the speed is $9.5 \mathrm{~mm}$ (measured internally). We chose the tube available on the market that best matched the calculated diameter: a tube $1 / 2$ inch $(12.7 \mathrm{~mm})$ in diameter, made of polypropylene.

The tube was $60 \mathrm{~cm}$ long. The air was injected at the base of the tube, beneath which we made holes of a size that would allow the entry of brine but would retain the olives. we made four holes of $1 \mathrm{~mm}$, $2 \mathrm{~mm}$ apart on another tube of $6 \mathrm{~mm}$ in diameter, whose function was to inject the air below the other. 


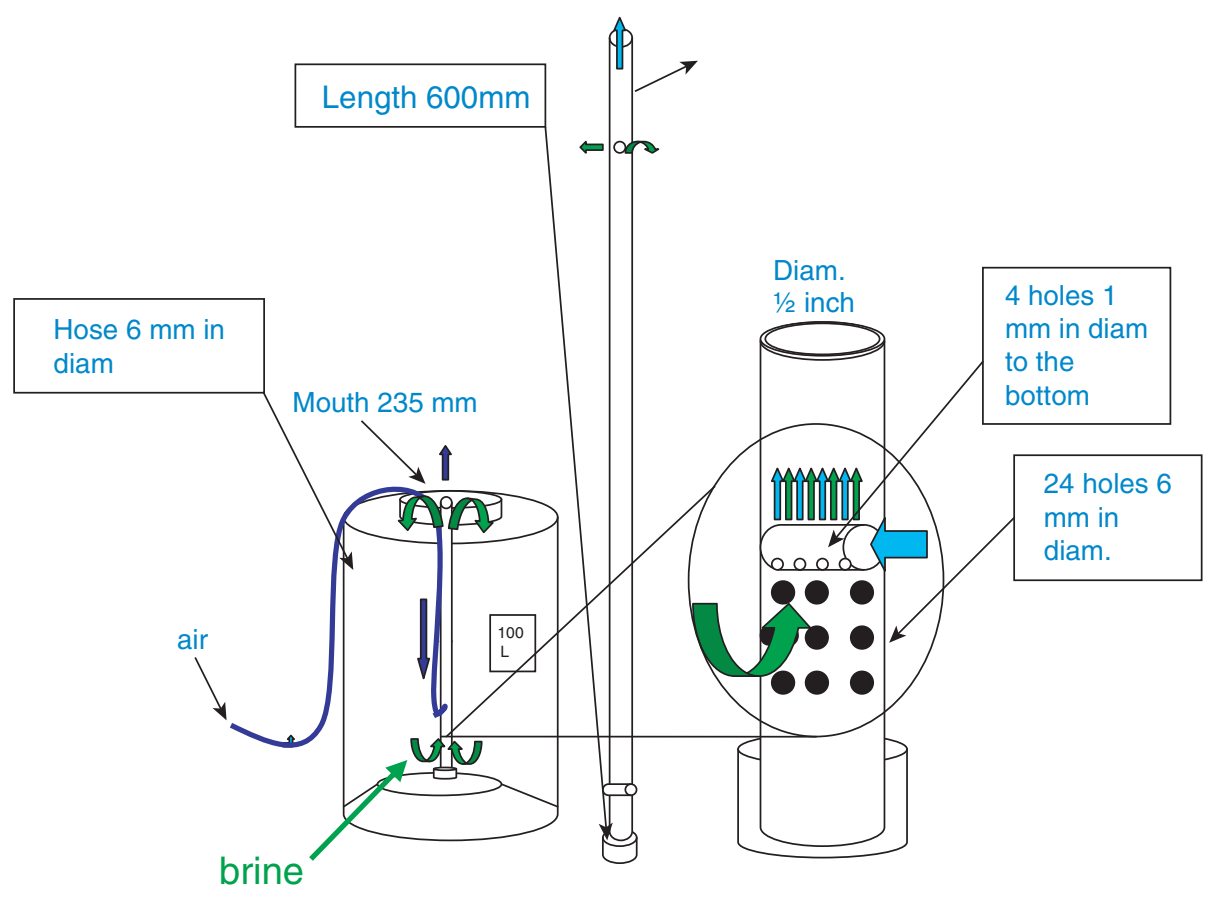

FIGURE 1. Diagram of the aeration device.
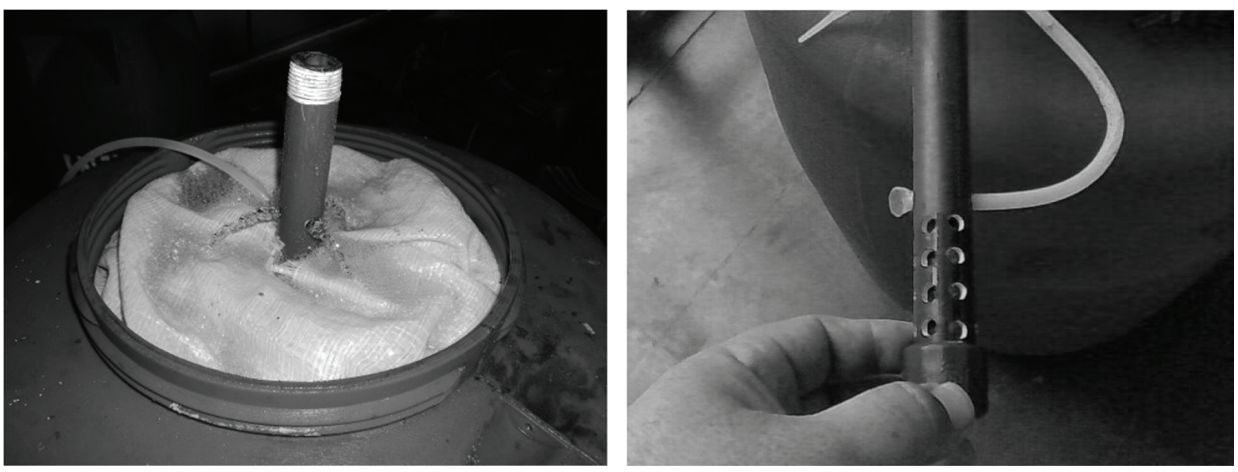

Figure 2. Images of the aeration system used.

A diagram of the system is detailed in Figure 1 and there are images in Figure 2.

To measure the air flow that entered the fermenters, we used ball Vortex flow meters, calibrated with a bubble flow meter. In all cases, we applied aeration for $8 \mathrm{~h}$ daily through the ignition by means of an automatic system, which is a similar regime to that of the industry (Garrido-Fernández et al., 1991).

\subsection{Description of the treatments}

\subsubsection{Conditions common to all treatments}

In all the cases, the fruits were washed three times by immersion in tap water for $12 \mathrm{~h}$ each time, removing the water after each immersion. Subsequently, the olives were placed in the container with a brine at $\mathrm{pH} 4.5$, adjusted with acetic acid up to 0.7 per thousand $\mathrm{v} / \mathrm{v}$ and divided into lots that were subjected (in duplicate) to the following treatments:

Traditional process, with initial brine at $2 \% \mathrm{NaCl}$ (T2). After washing, the olives were placed in brine at $2 \% \mathrm{NaCl}$. Subsequently, the olives were removed from the container and spread on trays ("extendido") to prevent contact among them. The trays were kept at room temperature $\left(25^{\circ} \mathrm{C}\right)$ for $24 \mathrm{~h}$, and then the olives were placed again in the initial brine. The "extendido" process was repeated three times, at 7, 14 and 21 days of fermentation. The $\mathrm{NaCl}$ concentration remained at $2 \%$ until the $\mathrm{pH}$ decreased to 4 and was then increased in two stages: first to $6 \%$ and then to $8 \%$ through the addition of solid salt. 
Intermittent aeration without "extendido" and initial brine at $2 \%(A 2)$. After washing, the olives were placed in brine at $2 \% \mathrm{NaCl}$ with air injection. Air was injected until the olives lost their bitterness and reached the flavor typical of this type of preparation. The $\mathrm{NaCl}$ concentration remained at $2 \%$ until the $\mathrm{pH}$ decreased to 4 and was then increased in two stages: first to $6 \%$ and then to $8 \%$ through the addition of solid salt.

Traditional process, with initial brine at 9\% $\mathrm{NaCl}$ (T9). After washing, the olives were placed in brine at $9 \% \mathrm{NaCl}$. Subsequently, the olives were removed from the container and spread on trays ("extendido") to prevent contact among them. The trays were placed at room temperature $\left(25^{\circ} \mathrm{C}\right)$. This process lasted $24 \mathrm{~h}$, after which the olives were placed again in the initial brine. The "extendido" process was repeated three times, at 7, 14 and 21 days after fermentation. The $\mathrm{NaCl}$ concentration was maintained at $9 \%$ by adding solid salt.

Intermittent aeration with an "extendido" and initial brine at 9\% (A9E). An initial brine at 9\% $\mathrm{NaCl}$, with air injection was used. Air was injected until the olives lost their bitterness and reached the typical flavor of this type of preparation. In this treatment, the olives were removed from the container and spread on trays ("extendido") to prevent contact among them. The trays were kept at room temperature $\left(25^{\circ} \mathrm{C}\right)$ for $24 \mathrm{~h}$, after which the olives were placed again in the initial brine. The "extendido" process was performed only once, at 7 days of fermentation. The $\mathrm{NaCl}$ concentration was maintained at $9 \%$ by adding solid salt.

It is important to note that the olives remain in the container until they lose their bitterness, and obtain the flavor which is typical of this type of preparation. Table 1 shows a summary of the treatments.

\subsection{Monitoring of the $\mathrm{pH}$ and $\mathrm{NaCl}$ concentration}

We used a Hanna Instruments $\mathrm{pH}$ meter Model Hi 9321. The saline concentration was measured with an airmeter with Baume scale, and the values were expressed as $\% \mathrm{w} / \mathrm{v}$ after the conversion by means of a table. We also used the Mohr method to determine the $\mathrm{NaCl}$ concentration in the fermentation brine (Garrido-Fernandez et al., 1991; Vogel, 1959).

\subsection{Analysis of the olives after fermentation}

\subsubsection{Proportion of "alambrado"}

The proportion of "alambrado" was estimated from a sample of 200 olives, taken from each fermenter after their homogenization. The olives were longitudinally cut and the alterations were evaluated by visual inspection. If no abnormality was detected, a second incision was made to repeat the assessment on the opposite side (Duran Quintana et al., 1986; García-García et al., 1982).

\subsubsection{Analysis of the texture}

To analyze the texture, we used a Stable Micro System Ltd. texturometer model TA-XT Plus equipped with a Kramer cell. The speed of the probe was $200 \mathrm{~mm} \cdot \mathrm{min}^{-1}$ and determinations were made on four pitted olives. Ten measurements were made for each treatment. The force was then expressed as N/100 g. The higher number indicates greater firmness (Arroyo López et al., 2005; Brenes et al., 1993; García et al., 1999).

\subsubsection{Colorimetry}

We used the CIE L*a*b* color space recommended by the Commission Internationale de léclairage in 1976 as an alternative to specifically distinguish the color of the light reflected by the samples (Fairchild, 2005). The measurement was made with a Konica Minolta CR-400 colorimeter which has a system of illumination/vision $\mathrm{d} / 0$ (diffuse lighting/view angle $0^{\circ}$ ). Three measurements were taken in different parts of the olive, averaging them to obtain an average value and thus obtain a representative variable for each olive. Measurements were made in 50 olives of each treatment (MontserratGonzález et al., 2007). The values obtained were used to estimate the population mean and its confidence interval. This measurement was performed on olives ready for consumption, which were kept for 30 days in new brine at $8 \% \mathrm{NaCl}$ and $\mathrm{pH} 4.0$.

TABLE 1. Summary of the treatments

\begin{tabular}{lcclc}
\hline $\begin{array}{l}\text { Name of the } \\
\text { treatment }\end{array}$ & $\begin{array}{c}\text { Initial NaCl concentration } \\
\text { of the brine (\%) }\end{array}$ & $\begin{array}{c}\text { Intermittent } \\
\text { Aeration } 8 \text { h daily }\end{array}$ & \multicolumn{1}{c}{ “Extendido” } & Container (L) \\
\hline A2 & 2 & Aeration & No & 100 \\
T2 & 2 & No & At 7, 14 and 21 days & 100 \\
T9 & 9 & No & At 7, 14 and 21 days & 100 \\
A9E & 9 & Aeration & At 7 days & 100 \\
\hline
\end{tabular}




\section{RESULTS}

\subsection{Analysis of the chemical evolution of the fermentation brines}

\subsubsection{Sodium chloride ( $\mathrm{NaCl}$ )}

Figure 3 shows the evolution of the $\mathrm{NaCl}$ concentration in the different treatments. In all cases, the $\mathrm{NaCl}$ concentration in the first days decreased due to its absorption by the olive pulp. This decrease is very difficult to predict since it depends on the volume and moisture of the olive, on the degree of permeability of the pulp tissues and on the lower or higher ability of the pulp to release and absorb solutes. In the treatments in which the initial concentration was $2 \%, \mathrm{NaCl}$ concentration increased in two stages: first to $6 \%$ and then to $8 \%$. At the same time, in the treatments where a concentration of $9 \%$ was used, we tried to maintain it constant. At the end of fermentation, in all the treatments, the concentration was taken to $8 \%$, as stipulated by the current legislation for conservation.

\subsubsection{Evolution of the $p H$ during the fermentation treatments}

As mentioned above, the control of the $\mathrm{pH}$ is a critical factor in the development of fermentation, since it determines the viability of the microorganisms present in the initial brine. In the initial brine, the $\mathrm{pH}$ value was corrected with acid acetic, and then allowed to develop freely (Figure 4). In the treatments where the initial concentration was $2 \%$ $\mathrm{NaCl}$ (A2 and $\mathrm{T} 2$ ), the $\mathrm{pH}$ decreased more rapidly, reaching lower values at the end of the fermentation process. This is consistent with that observed in previous works, with other varieties, since these conditions are more favorable for the development of lactic bacteria. In the treatments where the initial

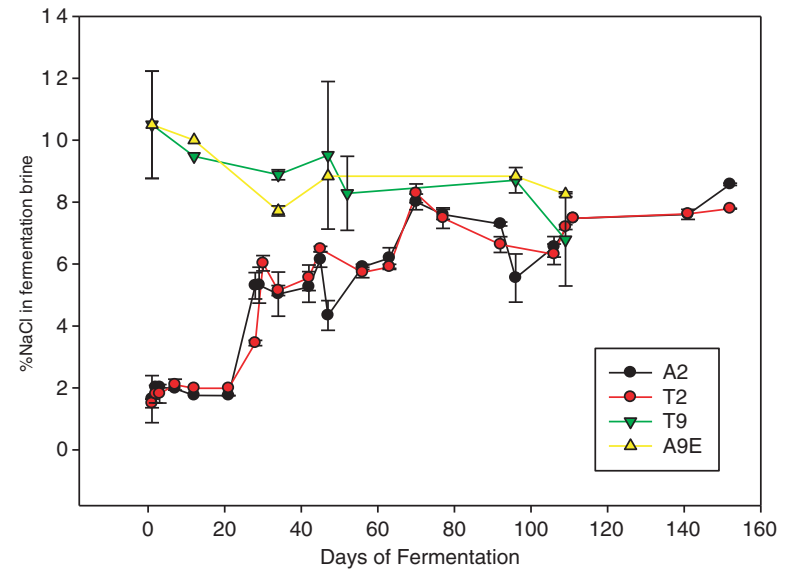

Figure 3. Evolution of the $\mathrm{NaCl}$ concentration during the fermentation process.

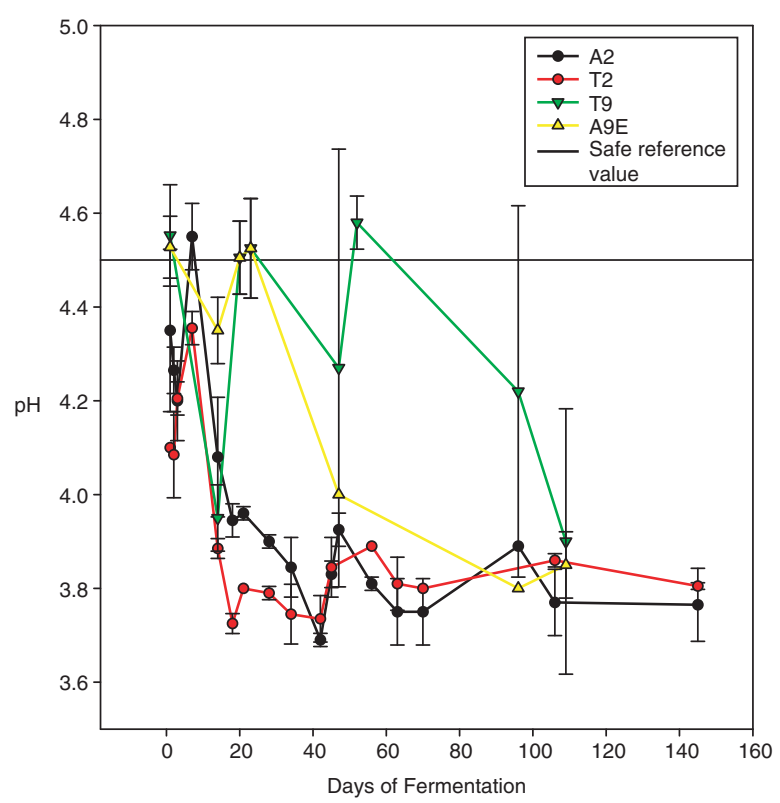

FiguRE 4. Evolution of the $\mathrm{pH}$ during the fermentation process.

concentration was 9\% $\mathrm{NaCl}$ (AE9 and T9), the $\mathrm{pH}$ decreased more slowly, presenting a greater variability between repetitions and reaching higher final values. This phenomenon has also been reported in previous works, explaining that high $\mathrm{NaCl}$ concentrations prevent a proper development of these bacteria (Duran Quintana et al., 1997; Salminen et al., 2004) and favor the growth of yeasts, which lack the ability to produce larger amounts of lactic acid than lactic bacteria.

\subsection{Spoilage of "alambrado"}

The "alambrado" is a defect that occurs in fermented olives and consists of the development of lesions in the pulp with an internal rupture of the continuity of the pulp with a gas space (Figure 5), which can be seen from the outside as a ring-shaped cut in the fruit and can be best seen when cutting the pulp.

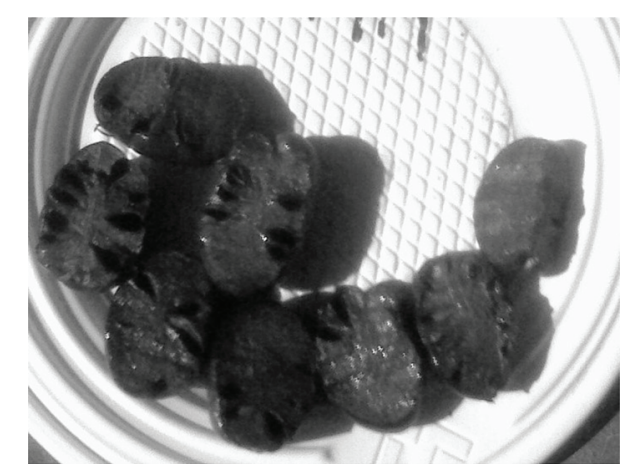

Figure 5. Spoilage known as "alambrado" in olives. Photo of the sampling of treatment T9. Damage is observed in the pulp. 
The analysis of olives clearly showed a very important decrease in the development of "alambrado" in the aerobic process (Figure 6), consistent with the lower levels of dissolved $\mathrm{CO}_{2}$, a factor which plays an important role in the appearance of the defect. This result confirms the motivations that led the researchers of the Instituto de la Grasa to propose the use of intermittent aeration in the processing of olives to prevent this defect. Some works have explained that this defect is the result of a high production of $\mathrm{CO}_{2}$ by some strict anaerobic fermentative yeast, such as Saccharomyces oleaginosus and Hansenula anomala. The aeration of the brine makes these species disappear and induces the growth of facultative yeasts or oxidative microorganisms. In this sense, it would be interesting to further investigations by isolating and identifying the species of yeast developed. On the other hand, the removal of $\mathrm{CO}_{2}$ from the brine favors the diffusion of the gas from the pulp through the barrier of the skin. This decreases the internal pressure and possible damages, such as the exudation of liquid and the formation of cracks (Garrido Fernández et al., 1997).

Previous studies carried out on the variety "Hojiblanca" have shown that the generation of $\mathrm{CO}_{2}$ in the pulp was the cause of the appearance of "alambrado". The origin of this gas could be the respiration of the olives, when switching from an aerobic metabolism to an anaerobic one, and/or the facultative anaerobic respiration of certain yeasts. Apparently, air injection allows the fruit to continue respiration (up to 50 days) without inducing

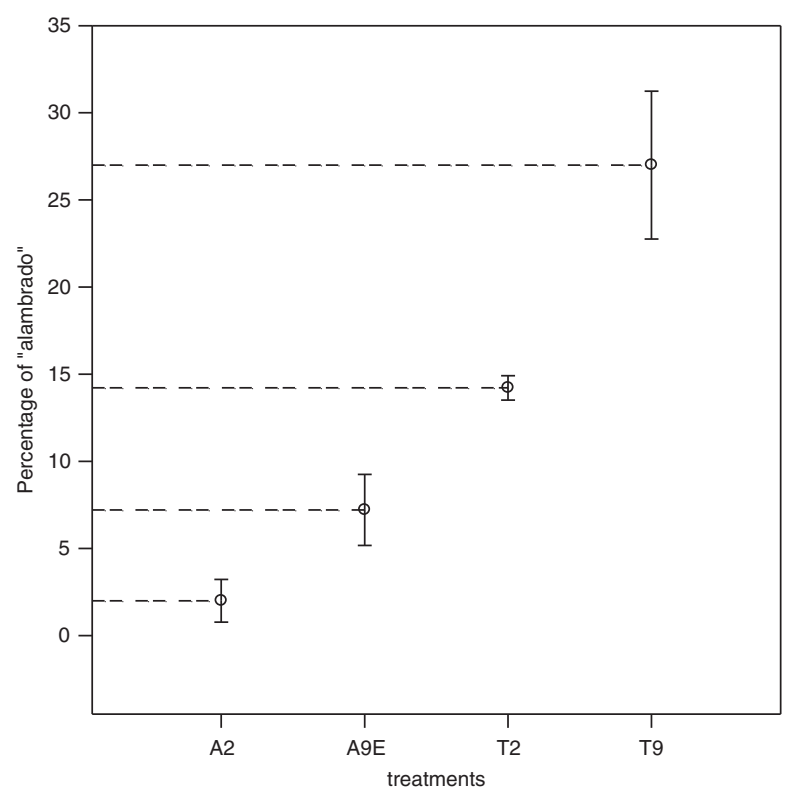

FIGURE 6. Percentage of olives with "alambrado" in olives prepared according to the different treatments. Graph of dispersion of the means in columns. anaerobiosis. This was deduced because, unlike aeration, neither $\mathrm{N}_{2}$ bubbling nor placing olives in sterile brine are able to reduce the defect (Duran Quintana et al., 1986; García-García et al., 1982; García-García et al., 1985).

In the present work, the percentage of "alambrado" of the control was not as high as that previously reported for fermentations started with $9 \%$ of $\mathrm{NaCl}$ and without aeration, where the percentage of olives with "alambrado" was 92\% (García-García et al., 1985).

Previous reports (Barranco et al., 2007) mention that beginning fermentation with $2 \% \mathrm{NaCl}$ and corrected $\mathrm{pH}$ are important factors to reduce the "alambrado" in Spanish black olive varieties. However, we observed that for the variety Arauco this is not sufficient since in $\mathrm{T} 2$ the percentage was $15 \%$ and that aeration helped to significantly reduce the defect.

\subsection{Texture}

The results of the measurement of the shear force required per gram of pulp were expected because the treatments without "extendido" were the ones with the highest values of resistance, confirming that the "extendido" spoils the texture. Aeration reduced the damage caused by the $\mathrm{CO}_{2}$ on the pulp (Table 2, means of shear forces). The results obtained with a single "extendido" were not significantly different from those obtained using no "extendido".

\subsection{Color}

The color of the olives that were harvested to initiate the processing was characterized by a maturity index of 4 . When assessing the assumptions to apply an analysis of variance (ANOVA) to parameters $L^{*}, a^{*}$ and $b^{*}$, we observed that they had a normal distribution (Shapiro-Wilks) but that the samples of the treatments had heterogeneous variances (Levene's test), and thus could not perform the ANOVA.

We modeled the heteroscedasticity and estimated the parameters of the variance function, and thus determined heterogeneity due to the treatment. We also carried out a one-way ANOVA on the KruskalWallis ranges (when the variances were not equal) and, since we found significant differences, we carried

TABLE 2. Means of the shear forces of the pulp of olives. Texture

\begin{tabular}{lcc}
\hline Treatment & $\mathbf{N} \cdot \mathbf{1 0 0 \mathbf { g } ^ { - 1 }}$ mean & SD \\
\hline T9 & $1625.1 \mathrm{a}$ & 279.2 \\
A9E & $1880.1 \mathrm{~b}$ & 229.9 \\
A2 & $1827.0 \mathrm{~b}$ & 264.0 \\
\hline
\end{tabular}

The same letter indicates that there are no significant differences between the means. 
TABLE 3. Estimators of the parameters of the variance function and medians of variable $\mathrm{L}^{*}$

\begin{tabular}{lcc}
\hline Treatments & $\begin{array}{c}\text { Estimator of the parameters of the } \\
\text { variance function of the population }\end{array}$ & Medians of $\mathbf{L}^{*}$ \\
\hline A2 & 1.00 & $45.642 \mathrm{c}$ \\
A9E & 0.76 & $34.476 \mathrm{~b}$ \\
T2 & 0.84 & $40.585 \mathrm{c}$ \\
T9 & 0.59 & $32.204 \mathrm{a}$ \\
\hline
\end{tabular}

The same letter indicates that there are no significant differences between the medians.

out a Dunn's multiple comparison test. We then analyzed the three variables of the CIE L*a*b* system, $\mathrm{L}^{*}, \mathrm{a}^{*}$ and $\mathrm{b}^{*}$.

$\mathrm{L}^{*}:$ is an indicator of the brightness or clarity of the color; lower values are expected in the case of black olives. Treatment A2 (without "extendido") led to the lowest darkness and greatest dispersion (Table 3, parameters of the variance function of L*). This confirms that the "extendido" reduces and homogenizes the luminosity. The greatest darkness was obtained with treatment T9 and with an "extendido" (treatment 9AE). This treatment reached $83 \%$ of the reduction in brightness reached by treatment $\mathrm{T} 9$ with respect to treatment $\mathrm{A} 2$ (Table 3; medians of $\mathrm{L}^{*}$ ).

$\mathrm{a}^{*}$ : (red-green) treatment A2 (without "extendido") was the one with largest variance. This confirms that the "extendido" homogenizes the colors, although the effect on the median of the treatments was not significant (Table 4, estimators of the parameters of the variance function of $\mathrm{a}^{*}$ ). The values of $a^{*}$ were the least influenced by these treatments (Table 4 , medians of variable a*).

b*: (yellow-blue) treatment A2 (without "extendido") was the one with the largest variance, which indicates that the "extendido" homogenizes the colors (Table 5, estimators of the parameters of the variance function of $\left.b^{*}\right)$. The values closer to yellow were those of the treatments at $2 \% \mathrm{NaCl}$, whereas the values farther from yellow were those of treatment T9. There were no significant differences between treatments A2 and T2 (Table 5, medians of variable $\mathrm{b}^{*}$ ).

TABLE 4. Estimators of the parameters of the variance function and medians of variable $a^{*}$

\begin{tabular}{lcc}
\hline Treatments & $\begin{array}{c}\text { Estimator of the parameters of the } \\
\text { variance function of the population }\end{array}$ & Medians of $\mathbf{a}^{*}$ \\
\hline A2 & 1.00 & $10.525 \mathrm{a}$ \\
T2 & 0.59 & $10.525 \mathrm{a}$ \\
T9 & 0.69 & $11.325 \mathrm{a}$ \\
A9E & 0.56 & $10.970 \mathrm{a}$
\end{tabular}

The same letter indicates that there are no significant differences among the medians.
TABLE 5. Estimators of the parameters of the function of the variance and medians of variable $b^{*}$

\begin{tabular}{lcc}
\hline Treatments & $\begin{array}{c}\text { Estimator of the parameters of the } \\
\text { variance function of the population }\end{array}$ & Medians of $\mathbf{b}^{*}$ \\
\hline A2 & 1.00 & $16.113 \mathrm{c}$ \\
T2 & 0.51 & $14.895 \mathrm{c}$ \\
T9 & 0.63 & $7.063 \mathrm{a}$ \\
A9E & 0.86 & $10.347 \mathrm{~b}$ \\
\hline
\end{tabular}

The same letter indicates that there are no significant differences between the medians.

Considering the three parameters together, it can be observed that the "extendido" and a $\mathrm{NaCl}$ concentration of $9 \%$ allow darker brown colors and that the lack of "extendido" and a $\mathrm{NaCl}$ concentration of $2 \%$ allow less dark colors which are closer to yellow (Figure 7 Box Plot, distribution of the CIE $\mathrm{L} * \mathrm{a} * \mathrm{~b} *$ values of the treatments).

\section{DISCUSSION}

\subsection{Evolution of $\mathrm{pH}$}

The results of the study show the significant effect of $\mathrm{NaCl}$ concentration on the decrease in $\mathrm{pH}$, which coincides with that reported for other varieties. This is explained by the impossibility of lactic bacteria to develop in $\mathrm{NaCl}$ concentrations higher than 8\% (Duran Quintana et al., 1997; Salminen et al., 2004), in which cases fermentation is carried out by yeasts. The results also showed the positive effect of using a low concentration of $\mathrm{NaCl}(2 \%)$, since this condition allows for a more rapid increase in acidity, with the consequent decrease in $\mathrm{pH}$, which is important for the conservation of the product.

\subsection{The "alambrado" spoilage}

The aeration treatment was very effective in reducing this typical defect in this type of processing of the Arauco variety, in agreement with that

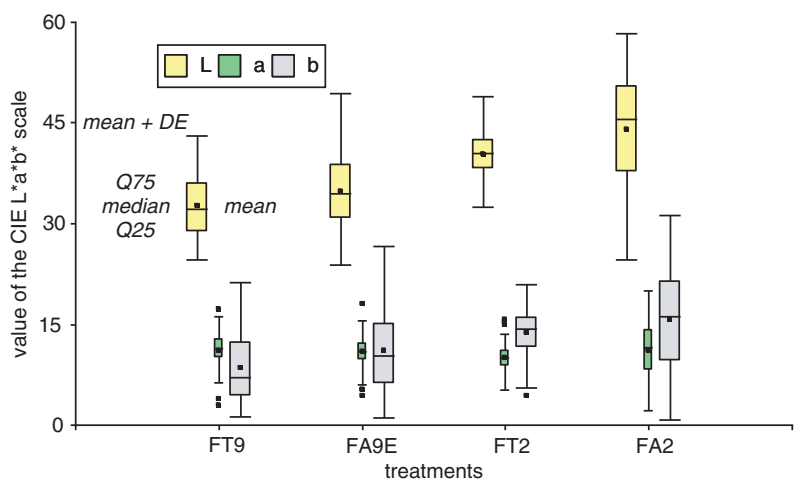

Figure 7. Box Plot with the distribution of CIE $L^{*} a^{*} b *$ values of the treatments. 
reported in previous works with other varieties (Duran Quintana et al., 1986; García-García et al., 1985). Although some works (Barranco et al., 2007) mention the use of a concentration of $\mathrm{NaCl}$ of $2 \%$ and the correction of the $\mathrm{pH}$ at the beginning of the fermentation process as important factors to reduce the "alambrado", our results show that this condition is insufficient for the Arauco variety, since in treatment T2 "alambrado" was reduced by only $15 \%$. Therefore, we propose $\mathrm{t}$ aeration and the use of an initial $\mathrm{NaCl}$ concentration of $2 \%$, since this procedure results in significantly reducing the defect.

Aeration reduces the "alambrado" by two possible mechanisms: one in which the anaerobic respiration of olives and the growth of strict anaerobic fermentative yeasts that produce the "alambrado", such as $S$. oleaginosus and $H$. anomala, are prevented and the growth of facultative (preferably) or oxidative microorganisms is induced; another in which the removal of $\mathrm{CO}_{2}$ from the brine by inhibition of anaerobic fermentation favors the diffusion of the gas from the pulp through the barrier of the skin, thus decreasing the internal pressure and possible damage, such as the exudation of liquid and the formation of cracks (Duran Quintana et al., 1986; Garrido Fernández et al., 1997).

\subsection{Texture}

The repeated "extendidos" spoil the firmness of the pulp. In contrast, aeration plus an "extendido" keeps the texture and improves the color. Improvements in texture allow for obtaining a more acceptable product and more time for its commercialization.

\subsection{Color}

The results show that aeration is not enough to match the effect of the "extendido". Thus, olives exposed to the "extendido", traditional in Argentina, presented a more homogeneous and darker color, which is considered a positive aspect in this product. In agreement with that reported in previous works (Duran Quintana et al., 1986), the results also showed the effect of the concentration of $\mathrm{NaCl}$ on parameter $b^{*}$. This is related to the higher acidity achieved during the fermentations carried out with lower salt percentages, since this condition favors the development of lactic bacteria. This increased acidity creates a reducing environment that is inhibitory to the activity of the enzyme polyphenoloxidaze. This enzyme causes the oxidation of polyphenols and favors the formation of melanins, which are associated with the development of the characteristic brown color.

Although we found that aeration is beneficial in reducing the "alambrado" in natural black olives of the Arauco variety, this treatment did not match the effect of the "extendido" for the development of the color. We suggest that future works should evaluate other aeration methods that allow a greater air contact with the skin of the olive. This could be achieved by increasing the air flow and/or changing the type of diffuser in the fermenter. This could favor a greater oxidation and thus allow for obtaining an effect comparable to that of the "extendido", with the great advantage of avoiding the stage of extraction of olives from the fermenters, since operating costs would be significantly reduced and the hygienic aspects of the process would be improved.

\section{ACKNOWLEDGEMENTS}

The study was financed by the National Institute of Agricultural Technology (INTA). We thank Ing. Agr. José Luis Ladux Director from INTA Chilecito, the Asociación de Pequeños Productores "Aimoarauco", Luis Claudio Sanow and the staff of the Instituto de Alimentos from INTA, Enrique Ríos of the Agencia de Extensión Rural de Aimogasta, Dr. Claudio Voget and Dr. Sebastián Cavallito from CINDEFI - Universidad Nacional de La Plata, La Plata, Argentina.

\section{REFERENCES}

Arroyo López FN, Romero C, Duran Quintana MC, López López A, García García P, Garrido Fernández A. 2005. Kinetic Study of the Pysicochemical and Microbiological Changes in "Seasoned" Olives during the Shelf-life Period. J. Agric. Food Chem. 53, 5285-5293. http://dx.doi.org/10.1021/ jf050501+.

Balastsouras G. 1996. Procesos de Elaboracion de Aceitunas de Mesa, in: Consejo-Oleicola-Internacional (Ed.), Enciclopedia Mundial del Olivo, Plaza \& Janés Editores S.A., Barcelona. Capítulo 8: pp. 523-549.

Barranco D, Fernandez-Escobar R, Rallo L. 2007. El Cultivo del Olivo, Junta de Andalucia - Mundi-Prensa, Madrid.

Brenes M, García García P, Garrido Fernández A. 1993. Influence of Salts and $\mathrm{pH}$ on the Firmness of Olives in Acid Conditions. J. Food Quality 17, 335-345. http://dx.doi. org/10.1111/j.1745-4557.1994.tb00155.x.

Durán Quintana MC, García-García P, Garrido Fernández A 1986. Fermentación en medio aeróbico de aceitunas maduras en salmuera con inyección alternante de Aire. Estudio de la influencia de la adición de cloruro calcico sobre la textura. Grasas Aceites 37, 242-247.

Durán Quintana M, Romero Barranco C, García García P, Brenes M, Garrido Fernández A. 1997. Bacterias del ácido láctico en la fermentación de aceitunas de mesa. Grasas Aceites 48, 297-311. http://dx.doi.org/10.3989/gya.1997. $\mathrm{v} 48.15 .806$.

Fairchild MD. 2005. Color appearance models. John Wiley\&Sons, New York.

García-García P, Durán-Quintana MC, Garrido-Fernández A. 1982. Modificaciones del proceso de fermentacion de aceitunas negras al natural para evitar alteraciones. Grasas Aceites 33, 9-17.

García-García P, Durán-Quintana MC, Garrido-Fernández A. 1985. Fermentación aeróbica de aceitunas maduras en salmuera. Grasas Aceites 36, 14-20.

Garcia P, Brenes M, Romero C, Garrido Fernández A. 1999. Color and Texture of Acidified Ripe Olives in Pouches. J. Food Sci. 64, 248-252. http://dx.doi.org/10.1111/j.1365-2621.1999. tb15875.x. 
Garrido-Fernández A, Heredia-Moreno A, Minguez-Mosquera M, Castro-Gomez-Millán A, Durán-Quitana MC, García-García P, Jiménez-Díez R., Rejano-Navarro L, Sanchez-Roldan F, Garrido-Fernandez J, Brenes M, Fernandez-Bolaños-Guzmán J, Gandul-Rojas B, GuillénBejarano R, Montaño-Asquerino A, Ruiz-Barba J, SánchezGómez A. 1985. Biotecnología de la aceituna de mesa in: Instituto de la Grasa y sus Derivados (Ed.), CSIC, Sevilla.

Garrido-Fernández A, Heredia-Moreno A, Minguez-Mosquera M, Castro-Gomez-Millan A, Duran-Quitana MC, GarciaGarcia P, Jimenez-Diez R, Rejano-Navarro L, SánchezRoldán F, Garrido-Fernández J, Brenes M, FernándezBolaños-Guzmán J, Gandul-Rojas B., Guillén-Bejarano R., Montaño-Asquerino A., Ruiz-Barba J, SánchezGómez A. (1991) Elaboración de Aceituna de Mesa. Boletín de servicios Agrícolas de la FAO N 81 in: FAOONU. (Ed.), FAO, Roma.

Garrido Fernández A, Fernández Díez JM, Adams MR. 1997. Table Olives: production and processing, Chapman \& Hall, London. http://dx.doi.org/10.1007/978-1-4899-4683-6.
Gobierno de la Pcia. de La Rioja. 2005. Protocolo de calidad para aceituna de mesa, in: M. d. I. C. y. Empleo (Ed.), Consejo Federal de Inversiones, La Rioja.

Lúquez Bibiloni CV, Aguilera Radic JM. 2006. El color en las Aceitunas Negras Naturales de mesa. Nueva técnica de mensura digitalizada para optimizar el metodo de oscurecimiento natural. Rev. FCA UNCuyo XXXVIII:10, $65-75$

Montserrat-Gonzalez M, Navarro T, Gomez G, Pérez RA, Lorenzo Cd. 2007. Analisis Sensorial de Aceituna de mesa. II. Aplicabilidad practica y correlacion con el analisis instrumental. Grasas Aceites 58, 231-236.

Romero MC. 1999. Pasos para la elaboracion de Aceituna Negra al Natural en Aimogasta, Aimogasta.

Salminen S, von Wright A, Ouwehand AC. 2004. Lactic Acid Bacteria: Microbiological and Functional Aspects. 3rd ed. Marcel Dekker Inc., New York.

Vogel AI. 1959. Quimica Analitica Cualitativa. 4ta ed., Kapelusz, Buenos Aires. 